\title{
ДО ПРОБЛЕМИ УПРАВЛІННЯ НАВЧАЛЬНО-ВИХОВНИМ ПРОЦЕСОМ У ЗАКЛАДАХ ОСВІТИ НА ЗАСАДАХ ЗДОРОВ'ЯЗБЕРІГАЮЧИХ ТЕХНОЛОГІЙ
}

\author{
С. В. Бондаренко
}

\author{
ДВНЗ “Тернопільський держсавниймедичний університет
}

імені І. Я. Горбачевського МОЗ Украӥни”

\section{TO THE PROBLEM OF EDUCATIONAL PROCESS MANAGEMENT IN EDUCATONAL ESTABLISHMENTS ON THE BASIS OF HEALTH CARE TECHNOLOGIES}

\author{
S. V. Bondarenko \\ SHEI "Ternopil State Medical University by I. Ya. Horbachevsky of MPH of Ukraine”
}

\begin{abstract}
У статті висвітлені деякі аспекти управління навчально-виховним процесом у закладах освіти на засадах необхідності ефективного впровадження здоров'язберігаючих технологій.

Some aspects of educational process management in educational establishments on the basis of the necessity of health care technologies implementation are analyzed in the article.
\end{abstract}

Вступ. На сьогодні головною проблемою, яка пов'язана з майбутнім держави, є збереження і зміцнення здоров'я дітей та учнівської молоді, вироблення стійких соціальних настанов щодо усвідомлення необхідності здорового способу життя, адже з кожним роком показники стану фізичного іпсихічного здоров'я населення, особливо молоді, значно погіршуються [1].

Відтак, у загальний зміст освіти інтегруються актуальні проблеми реального життя, питання екології, здоров'я, безпеки, а це відповідає вимогам нового державного стандарту [2]. На сучасну молодь все помітніше впливають чинники, дія яких раніше була значно меншою. Зокрема, мова йде про зниження фізичного навантаження, натомість підвищується нервово-психологічне, інформаційне. Стрімко поширюються серед молоді шкідливі звички. Тому зосередження уваги на проблемі психогігієнічного виховання і здорового способу життя серед молоді $є$ вкрай важливим. Здоровий спосіб життя - це все, що стосується збереження і зміцнення здоров'я, все, що сприяє виконанню людиною своїх людських функцій через діяльність з оздоровлення умов життя, праці, відпочинку, побут.

(C) С. В. Бондаренко
Саме тому доцільно охарактеризувати та розглянути проблему управління навчальним закладом (Н3) на наукових засадах здоров' язберігаючих технологій.

Проблема управління навчальним закладом $€$ чи не найважчою. Це природно, тому що зміни у нашому суспільстві щоразу кидають нам виклик, вимагають опановувати нові знання, вчитись використовувати їх на практиці.

Основна частина. Серед головних проблем сьогодення на одне з перших місць у державі в цілому та в освітній діяльності зокрема виходить проблема збереження здоров'я підростаючого покоління. Дослідниками відзначається катастрофічне зниження рівня здоров'я дітей та підлітків, що чинить негативний вплив на якість освітніх результатів. У зв'язку з цим, на думку фахівців, актуалізується проблема збереження здоров'я студентів, що спричиняє необхідність використання здоров'язберігаючих технологій у НЗ. Головним інструментом, за допомогою якого можна цього досягнути, - це скоординувати діяльність усіх структурних підрозділів, тобто організувати управління. Керівники НЗ освіти усіх управлінських ланок повинні опанувати цю важливу науку, уміло використовувати усі іï̈ важелі. Управління - це процес планування, організації мотивації і контролю, 
необхідний для того, щоб сформулювати і досягнути цілей організації. У нашому випадку ціль - це впровадження здоров' язберігаючих технологій в Н3. Існують і інші визначення управління:

- управління - це функція, вид діяльності з керівництва людьми у найрізноманітніших організаціях [3];

- управління - це уміння добиватися мети, використовуючи працю, інтелект, мотиви поведінки інших людей [4].

Визначення поняття управління американськими вченими звучить так: управління - робити що-небудь руками інших, тобто той, хто робить, не керує, хто керує - не робить [3].

Проблема управління є проблемою загальнонауковою, оскільки це предмет досліджень багатьох наук: менеджменту, економіки, соціології, юриспруденції, психології. У широкому розумінні поняття “'управління” визначають як елемент, функцію організованих систем, різних за природою, (біологічних, соціальних, технічних), що забезпечують збереження їх відповідної структури, підтримують режим діяльності та реалізацію їх програм. У контексті управління навчальними закладами такий феномен розглядають через методи і діяльність із забезпечення вимог якості освіти. Саме цим зумовлене в педагогіці виникнення нових напрямів - які стали соціальною галуззю наукового пізнання, що характеризується певним змістом, принципами, тенденціями та закономірностями розвитку.

Управління як невід'ємна частина педагогічної системи навчального закладу, iї системоутворююча засада, має об'єктивну природу, але за механізмом реалізації - це суб'єктивний процес. Воно може бути переважно інтуїтивним або спиратися на теоретичні основи науки. У зв'язку з цим надзвичайно важливо визначити, як співвідносяться практика і теорія управління [5].

В Україні вивченням проблеми управління навчальним закладом займаються вчені Л. Даниленко, Г. Дмитренко, Т. Сльнікова, О. Мармаза, С. Павлютенков, В. Крижко, Т. Рожнова, Б. Ренькас, С. Хриков. Однак розробка проблеми управління навчальним закладом на засадах здоров'язбереження знаходиться на початковій стадії.

У західній теорії управління освітніми установами $€$ чотири основні концепції управління [6].

Перша з них виникла на початку XX ст. Вона грунтується на критеріях економічної ефективності освітньої установи. В рамках цієї концепції освітня організація розглядається як закрита, механістична, раціональна система, управління якою націлено на забезпечення їі ефективності.
Друга концепція грунтується на критеріях педагогічної ефективності. Вона спирається на положення психологічної науки, а в аналітичному плані базується на аналізі досвіду адміністраторів навчальних закладів, які орієнтовані на принципи біхевіоризму. Освітню організацію представники цієї концепції розглядають як напіввідкриту, органічну, природну систему, управління якою спрямоване на інтеграцію складових елементів із метою оптимізації її функціонування. Акцент у цій концепції робиться на людських стосунках і управлінській поведінці.

Третя концепція управління базується на критеріях гнучкості. У концептуальному плані вона спирається на теорії управління розвитком, розвитку організаційних структур, теорії випадковості, інституціонального розвитку. Прихильники цієї концепції розглядають освітню організацію як відкриту й адаптивну систему. В процесі управління такою системою основне значення надається ситуаційним змінним зовнішнього середовища з метою забезпечення ії політичної гнучкості.

Четверта концепція управління базується на критеріях релевантності. В іiї основі - положення екзистенціоналізму, діалектичного методу, критичного реалізму і теорії людських стосунків. У рамках цієї концепції освітня організація розглядається як цілісна система елементів, що взаємодіють у процесі управління, у якій фахівці спираються на свідомість і критичність суб' єктів, суперечливість і спільність цілей у контексті культурної релевантності.

Найбільш сучасними, і не тільки за часом їх створення, вважають нині концепції управління, що базуються на критеріях гнучкості та культурної релевантності.

Розглянемо найбільш характерні підходи до управління, які використовуються в нашій державі. Одним iз представників традиційного підходу до розуміння сутності управління $є$ В. Пікельна. Вона розглядає управління як “вплив на керовану систему з метою максимального її функціонування, спрямованого на досягнення якісно нових завдань за рахунок циклічно здійснюваних переходів у якісно новий стан" [5].

Російські науковці розглядають управління навчальним закладом як специфічну діяльність, в якій іiі суб' єкти за допомогою планування, організації, керівництва й контролю забезпечують організованість (інтегрованість) спільної діяльності учнів, педагогів, батьків, обслуговуючого персоналу та ії спрямованість на досягнення освітніх цілей і цілей розвитку навчального закладу [7].

Немає єдності у поглядах на сутність управління, представлених у публікаціях українських науковців 
останніх років. Так, одні зазначають, що управління це діяльність, яка забезпечує планомірний і цілеспрямований вплив на управлінську систему з метою її максимального функціонування, інші розглядають управління як сукупність організаційних, методичних, кадрових та інших заходів, спрямованих на нормальне функціонування педагогічного процесу.

Підхід до управління як впливу має суттєві недоліки, оскільки управління реалізується через діяльність суб'єктів управління. У зв' язку з цим зазначимо, що управління реалізується через діяльність суб'єктів управління. Розгляд сутності управління через такий засіб взаємозв' язку, як вплив, є певною мірою доцільним, але не охоплює всіх особливостей цього явища [4].

Здоров'язберігаюча діяльність в освіті - міждисциплінарний, багатоаспектний і довготривалий процес, вимагає спеціальної підготовки усіх учасників навчально-виховного процесу до ії здійснення. Беручи до уваги чисельні визначення здоров'я та його складових (фізична, психічна, соціальна та духовна), можна стверджувати, що всі терміни, які використовуються в педагогічній літературі з коренем - здоров'я, стосуються стану організму, здатності особистості до саморегуляції поведінки, різних аспектів самопочуття та благополуччя людини тощо. Проаналізуємо трактування понять “збереження", “зміцнення” i “формування”. Звертаючись до словників, знаходимо, що термін “збереження” є похідним від слова “зберігати” й означає дію та стан:

1) оберігаючи, тримати цілим, не давати пропасти, зникнути; дбаючи, тримати що-небудь у доброму стані, намагатися залишити незмінним;

2) тримати що-небудь у певних умовах, оберігаючи від псування, руйнування; оберігати, захищати від чого-небудь згубного;

3) дбайливо ставитися до чого-небудь, не розтрачувати чогось; продовжувати залишатися в якомунебудь стані, не втрачати якихось ознак, властивостей, якостей [8]. Підготовка НЗ до здоров'язберігаючої діяльності - процес важкий та довготривалий. Найбільш продуктивними можна вважати такі методологічні підходи: аксіологічний, андрагогічний, акмеологічний, валеологічний, особистісно орієнтований, діяльнісний, системний.

3 позиції акмеологічного підходу підготовку педагогів слід розглядати як механізм розвитку професійної мобільності й вирішення нових завдань у соціокультурній і професійній діяльності.

Грунтуючись на положеннях акмеологічного підходу, освоєння здоров’ язберігаючої діяльності дослід- никами розглядається як чинник актуалізації “вершинних" можливостей педагогічної майстерності. Виокремлюють необхідність розробки моделі підготовки педагогів до здоров' язберігаючої діяльності як “нормативно-вікової моделі розвитку”.

У свою чергу, аксіологічний підхід дозволяє зорієнтувати систему педагогічної освіти на формування у фахівців реальних уявлень про справжні й уявні цінності життя, діяльність, здоров'я, на вибір стратегії взаємодії з навколишнім світом [9]. О. Сжова зазначає, що основними педагогічними чинниками формування цілісного ставлення до здоров'я є: освітнє середовище, всебічна діяльність суб' єктів педагогічного процесу, діяльність керівництва, педагогічного колективу, мотивація студентів та педагогів щодо здорового способу життя [10].

Системний підхід дозволяє формування здоров’язберігаючої компетентності керівника і педагогів як єдину систему, в якій увесь освітній процес організовується на принципах адекватності й здоров' язбереження, як процес формування здоров'я людини, природних та соціальних умов його збереження і зміцнення, що зорганізується як системний педагогічний процес у логічному зв' язку всіх його етапів і спрямовується на гармонійний і різнобічний розвиток особистості.

Андрагогічний підхід у системі педагогічної освітице спрямовуючий процес стимулювання, виховання, навчання й удосконалення дорослої людини під час професійної підготовки чи перепідготовки, який інтегрує надбання індивідуального, творчого, особистісно зорієнтованих підходів [9].

Валеологічний підхід передбачає створення таких педагогічних умов в освітній установі, які б забезпечили збереження та зміцнення здоров' я усіх суб' єктів освітнього процесу і вплинули на формування у них здоров' язберігаючої компетентності [11].

Діяльнісний підхід розглядає діяльність як головне джерело формування особистості і чинник ії розвитку. У цілому діяльнісний підхід передбачає орієнтацію на розвиток творчого потенціалу особистості і дозволяє врахувати індивідуальні й вікові особливості кожного студента за допомогою включення в діяльність, сприяє самореалізації і особистому зростанню [8].

Особистісно орієнтований підхід організовує здоров' язберігаючий освітній процес, в якому пріоритет надається інтересам і потребам особи, створенню безпечних і комфортних умов для іiі особистісного розвитку. Цей підхід припускає активну участь пе- 
дагога в освоєнні культури здоров’я, формуванні особистого досвіду здоров'язбереження, який отримується через поступове розширення сфери спілкування і діяльності педагогів, розвиток саморегуляції, відповідальність за своє здоров'я, життя і здоров’я інших людей [12].

Н. Денисенко зазначає, що ефективне застосування особистісно орієнтованих технологій передбачає створення здоров'язберігаючих і здоров'яформуючих умов, основними серед яких є: розвиток тіла i фізіологічних систем організму, розвиток пізнавальних процесів, формування психічних станів, вільний природний прояв позитивних емоцій, розвиток особистісних якостей, подолання негативного ставлення до особистого здоров'я, життя власне себе та інших людей [13].

Також у сучасній теорії управління необхідно враховувати принципи організації управлінської діяльності, а в нашому випадку-це принципи організації здоров'язберігаючої діяльності:

- принцип переходу до ціннісної парадигми виховання;

- принцип природодоцільності;

- принцип педагогічної підтримки (педагогічного супроводу);

- принцип безперервності та наступності;

- принцип інтеграції зусиль суб'єктів навчальновиховного процесу, спрямованих на забезпечення розвитку фізичного та психічного здоров'я студентів; - принцип гармонійного розвитку особистості;

- принцип оздоровчої спрямованості навчальновиховного процесу.

Ряд авторів виділяє такі фактори впливу на стан здоров'я учасників освітнього процесу: соціальні (соціальна орієнтація на здоровий спосіб життя, стійка мотивація до здоров' язберігаючої поведінки, усвідомлена потреба у валеологічних знаннях та навичках тощо); психолого-фізіологічні (функціональний стан організму, індивідуально-типологічні особливості організму, відповідні погляди та переконання щодо здоров’ я, усвідомлення значущості здоров' я тощо), організаційно-педагогічні, які поділяються на організаційні (навчальний процес, побудова розпорядку дня, режим рухової активності), процесуальні (освітній стандарт, розумові та фізичні навантаження) та професійно-компетентнісні (антистресова педагогічна тактика, мотивований, комплексний підхід педагога до оцінки стану здоров'я учнів, використання здоров'язберігаючих технологій, систематичний моніторинг стану здоров' я учнів, застосування адекватних діагностичних методик), управлінські (основні параметри функціонування здоров' язберігаючого середовища навчального закладу, матеріально-технічні, фінансові, кадрові, інформаційні, методичні ресурси тощо) [14].

Дані фактори поглиблюють розуміння сутнісних характеристик здоров'язберігаючого середовища, підкреслюючи необхідність комплексного підходу до його створення. Під час проектування здоров'язберігаючого середовища навчального закладу необхідно забезпечити такі педагогічні умови:

- розробку та затвердження здоров'язберігаючої концепції, формулювання стратегічних цілей та завдань;

- здійснення діагностики та моніторингу стану здоров'я студентів;

- прилучення студентів до основ здорового способу життя, формування валеологічної компетентності; - підвищення професійної компетентності педагогічного колективу в контексті здоров'язберігаючої діяльності, формування культури здоров'я;

- змістовну взаємодію всіх суб'єктів педагогічного процесу (адміністрації, викладачів, інструкторів 3 фізичної культури, психологів, медичних сестер, студентів, батьків), визначення їхніх обов'язків та відповідальності в реалізації програмних цілей [15].

Основними показниками ефективності функціонування здоров'язберігаючого середовища є такі: матеріально-технічна забезпеченість здоров'язберігаючого середовища, їх відповідність санітарногігієнічним нормам; відповідність організації системи харчування чинним санітарним правилам та нормам; міжособистісні взаємини між суб' єктами навчальновиховного процесу; стан фізичного та психічного здоров’я студентів і викладачів; показники рухової підготовленості учнів, рівень професійної компетентності педагогів, цілісність оздоровчих впливів та стабільність результатів [14].

Висновки. Отже, створення здоров'язберігаючого середовища - процес, який вимагає чіткого усвідомлення усіма суб' єктами навчально-виховного процесу значущості відповідального ставлення до власного здоров'я. Таке середовище має забезпечувати не лише збереження та зміцнення здоров'я студентів, а й формування культури здоров'я. Лише злагоджена та змістовна співпраця навчального закладу та родини у сфері здоров' язбереження зможе забезпечити успішну реалізацію здоров' язберігаючих технологій, спрямованих на покращення стану здоров'я студентів. 


\section{Списокл літератури}

1. Ковалько В. И. Здоровьесберегающие технологии: школьник и компьютер: 1-4 классы / В. И. Ковалько. М. : ВАКО, 2007.-304 c.

2. Сериков Г. Н. Здоровьесбережение в гуманном образовании / Г. Н. Сериков. - Екатеринбург ; Челябинск, 1999. $242 \mathrm{c}$.

3. Вознюк Т. Г. Менеджмент навчально-виховного процесу / Т. Г. Вознюк. -К. : Здоров'я, 2002. - 128 с.

4. Освітні технології : навчально-методичний посібник [О. М. Пєхота, А. З. Кіктенко, О. М. Любарська та ін.] ; за заг. ред. О. М. Пехоти. -К. : А.С.К., 2001.-256 с.

5. Пикельная В. С. Теория и методика моделирования управленческой деятельности (школоведческий аспект) : дис. ... доктора пед. наук: 13.00.01 / В. С. Пикельная. К., 1993.-374 c.

6. Мармаза О. І. Менеджмент в освіті: дорожня карта керівника / О. І. Мармаза. - Харків : Основа, 2007. - 448 с.

7. Хміль Ф. І. Менеджмент : підручник / Ф. І. Хміль. К. : Вища шк., 1995. - 351 с.

8. Великий тлумачний словник сучасної української мови / уклад. і голов. ред. В. Т. Бусел. - К. ; Ірпінь : ВТФ "Перун", 2004.- 1440 с.

9. Буренко В. М. Андрогогічний підхід до професійної підготовки вчителя гуманітарного профілю : автореф. дис. канд. пед. наук : 13.00.04 - теорія і методика професійної освіти / В. М. Буренко. -К., 2005. -21 с.
10. Єжова О. О. Здоровий спосіб життя : навчальний посібник для студентів професійно-технічних навчальних закладів / О. О. Сжова. - Суми : Університетська книга, 2010. $-126 \mathrm{c}$.

11. Сериков С. Г. Обеспечение паритета образованности и здоровья учащихся в теории и практике образования : дис. ... доктора пед. наук: 13.00.01 / 13.00.04 / С. Г. Сериков. Челябинск, 2002. -385 с.

12. Сжова О. О. Педагогічні фактори і умови формування ціннісного ставлення до здоров'я / О. О. Сжова // Вісник Глухівського державного педагогічного університету імені Олександра Довженка. Серія : Педагогічні науки. - Глухів : ГДПУ, 2009.- Вип. 14.-С. 159-164.

13. Денисенко Н. Ф. Освітній процес має бути здоров'язбережувальним / Н. Ф. Денисенко // Дошкільне виховання. -2007 . - № 7. - С. 8-10.

14. Сергієнко В. Запровадження в навчальний процес моделі Школи культури здоров'я / В. Сергієнко // Практика управління закладом освіти. -2009. - № 12.-С. 23.

15. Видюк А. П. Формирование культуры здоровья в образовательных программах / А. П. Видюк, Е. А. Демьяненко, Л. В. Белогурова // Здоровье и образование: проблемы и перспективы : материалы Всеукр. науч.метод. конф. / гл. ред. А. Г. Рыбковский. - Донецк : ДонГУ, 2000.-C. 18-20. 